\title{
Persistence of fluazinam in soil under boreal conditions
}

\author{
Hakala, Kati P.
}

2020-06-02

Hakala , K P , Yli-Halla , M J , Tuomainen , P M \& Hartikainen, H 2020 , ' Persistence of fluazinam in soil under boreal conditions ', Journal of Environmental Science and Health. Part B: Pesticides, Food Contaminants, and Agricultural Wastes , vol. 55 , no. 6 , pp. 539-549 . https://doi.org/10.1080/03601234.2020.1729631

http://hdl.handle.net/10138/326896

https://doi.org/10.1080/03601234.2020.1729631

acceptedVersion

Downloaded from Helda, University of Helsinki institutional repository.

This is an electronic reprint of the original article.

This reprint may differ from the original in pagination and typographic detail.

Please cite the original version. 


\title{
Persistence of fluazinam in soil under boreal conditions
}

\author{
Kati P. Hakala ${ }^{1 *}$, Markku J. Yli-Halla ${ }^{1}$, Päivi M. Tuomainen ${ }^{2}$, and Helinä Hartikainen ${ }^{1}$ \\ ${ }^{1}$ Department of Agricultural Sciences, University of Helsinki, Helsinki, Finland \\ ${ }^{2}$ Department of Food and Nutrition, University of Helsinki, Helsinki, Finland
}

\begin{abstract}
Fluazinam, a widely used pesticide in conventional potato cultivation, is effective against epidemics of the fungal disease late blight. To assess fluazinam persistence in soil, laboratory experiments were conducted with fluazinam added to soil as a pure chemical or contained in the commercial product Shirlan ${ }^{\circledR}$. In a follow-up experiment, the persistence was monitored under constant temperature and water content conditions during a maximum period of 1 year. In an annual climatic rotation experiment, fluazinam added to soil was exposed to the yearround temperature and water content conditions occurring in the boreal zone. A third experiment was undertaken to clarify the effect of soil organic matter (SOM) on the recovery of fluazinam. In the follow-up and annual climatic rotation experiments, more than half of the added fluazinam was recovered after 1 year of incubation. The estimated half-life of fluazinam ranged between 355 and 833 days. The degradation of fluazinam was enhanced by an abundance of SOM, a warm temperature, and wetness. Additionally, in over half of soil
\end{abstract}

\footnotetext{
* Address correspondence to Kati P. Hakala, Department of Agricultural Sciences, University of Helsinki, Viikinkaari 9, FI-00790 Helsinki, Finland; E-mail: kati.p.hakala@helsinki.fi
} 
samples collected from fields where potato had been intensively cultivated for many years, varying concentrations of fluazinam were detected. Fluazinam can carry over to the next growing season in professional potato production.

KEYWORDS: Pesticide; Shirlan ${ }^{\circledR}$; degradation; potato late blight; high-performance liquid chromatography

\section{Introduction}

Potato (Solanum tuberosum) is a widely used daily staple food, particularly in Europe, North America, and parts of Asia. In Finland, its yearly consumption is about 285 million kg, corresponding to about $52 \mathrm{~kg}$ per person, ${ }^{[1]}$ and in 2016, the arable land area used for potato cultivation totaled 21,900 ha. ${ }^{[2]}$ One of the most damaging potato diseases worldwide is potato late blight (Phytophthora infestans (Mont.) de Bary). ${ }^{[3]}$ Fluazinam (3-chloro-N-(3chloro-5-trifluoromethyl-2-pyridyl)- $\alpha, \alpha, \alpha$-trifluoro-2,6-dinitro-p-toluidine, CAS No. 7962259-6) (Fig. 1), belonging to the chemical group of phenylpyridinamines, is a fungicide widely used against late blight epidemics of potato.

Fluazinam is an effective contact fungicide that inhibits fungal respiration and the production of energy within the fungus. ${ }^{[4]}$ It also adversely affects luminescent soil bacteria, the vegetative vigor of terrestrial vascular plants, freshwater and marine organisms, and the dietary and reproductive capacity of wild mammals. ${ }^{[5,6]}$ Arguments for the severe toxicity of fluazinam to soil organisms have been presented. In terms of ecotoxicity, fluazinam is considered to be a hazardous pesticide. ${ }^{[7]}$ In a Finnish study, fluazinam was demonstrated to be highly toxic in a microcosm test but less toxic in mesocosm and field tests. ${ }^{[8]}$ 
In Finland, the commercial product Shirlan ${ }^{\circledR}$ (containing $50 \% \mathrm{w} \mathrm{v}^{-1}$ fluazinam) is normally sprayed onto potato foliage several times at the end of the spraying schedule. Its maximum individual dose is $0.4 \mathrm{~L} \mathrm{ha}^{-1}$ (corresponding to $200 \mathrm{~g} \mathrm{ha}^{-1}$ fluazinam) mixed with water, the maximum number of applications is 10 per crop, and the latest spraying time is 7 days before the harvest. An unsprayed 5-meter buffer zone adjacent to surface water bodies is recommended. In Finland, it is not recommended to use fluazinam on the same field plot in consecutive growing seasons in potato cultivation. ${ }^{[9]}$

Fluazinam ends up in soil during spraying and at the end of the growing season, when potato foliage is incorporated into the soil. It is generally classified as non-persistent or moderately persistent in soil. Fluazinam is not readily biodegradable, its mineralization is almost negligible, and photolysis may contribute moderately to its environmental dissipation in soil. ${ }^{[10]}$ Its degradation is enhanced by anaerobic conditions and a high soil organic matter (SOM) content. ${ }^{[10-12]}$ Fluazinam degradation has been found to be most effective at the beginning of experiments. ${ }^{[9]}$ The reported degradation half-life (DT50) values obtained in field experiments carried out in China, Germany, and Finland have varied significantly, from 1-4 days ${ }^{[13]}$ to $8-41$ days ${ }^{[10]}$ and even $45-165$ days. ${ }^{[14]}$ The European Food Safety Authority ${ }^{[10]}$ (EFSA) demonstrated that the DT50 of fluazinam in soil is 17-226 days under aerobic and 426 days under anaerobic conditions.

The $\log K_{\text {ow }}$ (octanol/water partition coefficient) of 4.03 indicates that fluazinam is weakly polar and has low water solubility. ${ }^{[11]}$ Thus, its retention most probably occurs via physical sorption onto SOM. Chloro groups, in particular, increase the molecular volume of the compound, which assists its sorption onto SOM by hydrophobic attraction. ${ }^{[15]}$ Thus, a high 
SOM content can notably increase the sorption tendency and favor its accumulation. The strong binding onto soil particles as well as the chloro and fluoro substituents in the fluazinam molecule retard microbiological degradation and photodegradation on the soil surface. ${ }^{[16]}$ The gradual accumulation of pesticides with slow degradation tendencies is possible in professional potato production, which is often based on long-term monoculture. In fact, fluazinam is reported to accumulate in soil ${ }^{[9]}$ and to be preserved to the next growing season. ${ }^{[8,11]}$ According to the Ministry of Water and Environment, ${ }^{[17]}$ the proportion of fluazinam bound to soil particles was striking in a Finnish soil, being $47 \%$ of the added amount after 180 days under aerobic and $60 \%$ under anaerobic conditions.

Fluazinam displays little movement downwards in soil in the dissolved form, but in soils subjected to erosion, it can be transported with detached soil particles to watercourses. In a study undertaken in Canada, fluazinam was not found to leach through soil layers, ${ }^{[11]}$ while a study in Denmark was unable to detect fluazinam in leachates from landfills. ${ }^{[18]}$ In a field experiment conducted on a silty soil in Finland, $0.01 \%$ of the fluazinam applied was transported with surface runoff, whereas the fungicide was not detected in subsurface drainage water. ${ }^{[14]}$

In Finland, the cold temperatures retard the degradation of fluazinam in soil. ${ }^{[9]}$ During winter, the topsoil is commonly frozen for several months each year, and even in Southern Finland, the mean temperature in surface soil $(0-5 \mathrm{~cm})$ exceeds $10^{\circ} \mathrm{C}$ only during 4 months per year and the mean soil temperature in July is $15^{\circ} \mathrm{C}$ at the depth of $20 \mathrm{~cm} .{ }^{[19]}$ Consequently, the degradation of fluazinam slows down in winter, ${ }^{[20]}$ which contributes to the retention of its potential bioavailability over winter. ${ }^{[8]}$ 
Few studies have been conducted on the behavior of fluazinam in soil, especially in the boreal zone, where the characteristic low $\mathrm{pH}$ and low temperatures delay microbiological decomposition. Furthermore, in boreal conditions, the annual variation in temperature is large, with cold winters and a short growing season of about 170 days in Southern Finland and 110 days in Northern Finland. ${ }^{[21]}$ In the humid boreal climate, the soils are saturated by water for long periods in autumn, winter, and spring, but the low temperature may not be conducive to the development of anaerobic conditions. On the other hand, soil in the boreal zone is typically high in SOM, which promotes the degradation of fluazinam through high microbiological activity. ${ }^{[14]}$ Therefore, information on the net effect of environmental conditions on the persistence of fluazinam in boreal conditions is needed to predict the potential environmental risks of this pesticide. This information is needed because more aggressive strains of Phytophthora infestans have spread to northern latitudes, which will further increase the need to use fungicides. ${ }^{[22]}$

The aim of this study was to assess the persistence of fluazinam under various temperature and water content conditions in the boreal zone soils differing in SOM content. Three laboratory experiments were conducted with fluazinam added to soil as a pure chemical (fluazinam standard) or in the commercial product Shirlan ${ }^{\circledR}$ (containing $50 \% \mathrm{w} \mathrm{v}^{-1}$ fluazinam), which is directly sprayed onto potato foliage as an aqueous solution in potato cultivation. First, in a follow-up experiment on plow layer soil and subsoil, the recovery of fluazinam was monitored under constant temperature and water contents during a maximum period of 1 year. Second, in an annual climatic rotation experiment, the recovery of added fluazinam from topsoil and subsoil was monitored under conditions simulating the temperature and water content conditions of the boreal zone for a maximum period of 1 year. Third, the effect of SOM on the degradation of fluazinam was examined using soil samples before and after the 
removal of SOM. In addition to these laboratory experiments, soil samples were collected from fields under long-term potato monoculture. They were analyzed for fluazinam residues to assess the degradation and accumulation of this fungicide.

\section{Materials and methods}

\section{Soil samples}

Soil samples were collected from potato fields located in Helsinki (Province of Uusimaa) and in Ylistaro and Kurikka (Province of Southern Ostrobothnia) (Fig. 2). The soil samples for the follow-up, annual climatic rotation, and SOM experiments were collected from two depths of a sandy field at the Viikki research farm of the University of Helsinki. These fields have never been treated with fluazinam. To obtain paired soil samples with a similar texture but differing in SOM content, they were collected from the plow layer (topsoil, 0-20 cm) and from the subsoil underneath (20-35 cm). According to the World Reference Base for Soil Resources

(WRB) classification system, ${ }^{[23]}$ the soils were Endogleyic Arenosols. Their properties are presented in Table 1.

The Viikki soil samples were homogenized, crushed to pass through a 2-mm sieve, and stored at $5^{\circ} \mathrm{C}$. Air-dried subsamples were used to determine the chemical soil properties. SOM was analyzed as the loss-on-ignition, assuming that the weight loss is equal to the SOM content. The potential cation-exchange capacity $\left(\mathrm{CEC}_{\mathrm{pot}}\right)$ was determined as the sum of cations replaced by four subsequent extractions with $1 \mathrm{M}$ ammonium acetate (pH 7). Soil $\mathrm{pH}$ was measured in a $0.01 \mathrm{M}$ calcium chloride suspension (1:2.5). 
In Southern Ostrobothnia, soil samples were collected in the regions of Ylistaro and Kurikka from commercial potato fields where long-term intensive potato cultivation had been practiced, in some fields even for decades. In October 2013, topsoil (0-10 cm) samples were taken after the growing season. On the basis of a preliminary study, fluazinam was not found in the subsoil, and only topsoil samples were therefore collected. Most of the fields had been sprayed with Shirlan ${ }^{\circledR}$ during the same growing season and many fields for a number of years. A total of 30 topsoil samples were collected from 15 different fields of five farms and one research institute. All samples were stored at $5^{\circ} \mathrm{C}$, homogenized, crushed to pass through a 2$\mathrm{mm}$ sieve, and air-dried before fluazinam analysis. The air-dried subsamples were analyzed for SOM using the loss-on-ignition method and their $\mathrm{pH}$ was measured in a $0.01 \mathrm{M} \mathrm{CaCl}_{2}$ suspension (1:2.5). The farmers provided information on the soil types and the number of sprayings applied prior to soil sampling.

\section{Experimental designs}

A follow-up experiment was conducted to monitor the persistence of fluazinam in topsoil and subsoil under different temperature and water content conditions during a maximum period of 1 year. Initially, the water content of the homogenized soil samples was adjusted to about $25 \%$ for topsoil and $20 \%$ for subsoil (lower in SOM) or the samples were waterlogged. Moisturizing was performed because Finnish soils are moist for the majority of the year. Then, 25-g portions of soil samples were treated in triplicate with the fluazinam standard (dissolved in acetone) or Shirlan ${ }^{\circledR}$ (dissolved in water) by spraying with a syringe. The volume of solution sprayed was only $1 \mathrm{~mL}$ to minimize any side effects on the indigenous microbial population and degradation patterns. ${ }^{[24]}$ The fluazinam standard (purity 98.5\%) was purchased from Sigma-Aldrich Corporation (St. Louis, MO) and the commercial product 
Shirlan ${ }^{\circledR}$ (containing 50\% $\mathrm{w} \mathrm{v}^{-1}$ fluazinam) from Syngenta (ISK Biosciences Europe SA, Diegem, Belgium). In both cases, the fluazinam addition was $2.5 \mathrm{mg}$ (corresponding to about $\left.2 \mathrm{~kg} \mathrm{ha}^{-1}\right)$, i.e. 10 times higher than the normal application rate $\left(0.4 \mathrm{~L} \mathrm{Shirlan}^{\circledR} \mathrm{ha}^{-1}\right)$, assuming a homogeneous distribution of the chemical on the surface of the plow layer. The tenfold excess was incorporated into the soil to obtain clearly observable fluazinam residues in the analyses. Finally, the samples were incubated in constant-temperature rooms in darkness at $5^{\circ} \mathrm{C}$ or $22^{\circ} \mathrm{C}$ for $90,180,270$, or 360 days. The maximum of 1 year as a reference period was chosen to obtain a reliable estimate of degradation ${ }^{[25]}$ and because in potato monoculture it is possible to respray Shirlan ${ }^{\circledR}$ in the next growing season. During the incubation, the water content was checked every month, but it was not necessary to add any water. The samples were not stirred during the experiment.

An annual climatic rotation experiment was conducted to monitor the persistence of fluazinam in topsoil and subsoil. It simulated the year-round temperature and water content conditions typical of soil in the boreal zone. The moisturizing and the spraying of the soil samples were performed in triplicate, similarly as in the follow-up experiment described above. During the first 90 -day incubation step at $22^{\circ} \mathrm{C}$, the constant water content was about $25 \%$ in topsoil and $20 \%$ in subsoil. This combination of temperature, time, and water content was taken to simulate summer conditions. Thereafter, to mimic cool and wet autumn conditions, the samples were flooded and incubated at $5^{\circ} \mathrm{C}$ for 90 days. Then, the samples were exposed to winter conditions of $-7^{\circ} \mathrm{C}$ for 90 days and finally to $5^{\circ} \mathrm{C}$ for 90 days, still in a waterlogged state, simulating snow melting (spring). During this experiment, the samples were kept in darkness and they were not stirred to avoid unintended oxidation reactions. In all sample sets the fluazinam concentration was determined after each 90 -day incubation step by using all the sample from the incubation bottles. 
A third experiment was undertaken to directly assess the effect of SOM on the behavior of fluazinam. In this experiment, SOM was removed from air-dried topsoil and subsoil samples by using $30 \%$ hydrogen peroxide $\left(\mathrm{H}_{2} \mathrm{O}_{2}\right){ }^{[26]}$ purchased from Merck \& Co., Inc. (Whitehouse Station, NJ). Then, the soil samples were air-dried, sprayed with fluazinam standard or Shirlan ${ }^{\circledR}$ in triplicate as in the follow-up experiment, and incubated for 90 days at room temperature in darkness. Corresponding air-dried samples without SOM removal were sprayed and incubated in the same manner.

\section{Soil analyses}

The fluazinam concentration in soil was analyzed immediately after each incubation period. The method used is described in detail by Hakala et al. ${ }^{[27]}$ Briefly, fluazinam was extracted from $25 \mathrm{~g}$ of sample soils with acetonitrile in triplicate. Then, after filtration and solvent change to heptane, the extract was purified using solid-phase extraction (SPE) with a mixture of diethyl ether and heptane (20:80). Finally, after nitrogen $\left(\mathrm{N}_{2}\right)$ evaporation, the fluazinam concentration was analyzed by HPLC-DAD (high-performance liquid chromatography equipped with a diode-array detector) in acetone. Strata ${ }^{\circledR}$ SI-1 silica cartridges (500 mg) were

purchased from Phenomenex (Torrance, CA), HPLC-grade acetonitrile, heptane, and acetone from Rathburn Chemicals (Walkerburn, UK), and diethyl ether from Merck \& Co., Inc. (Whitehouse Station, NJ).

Analyses of fluazinam were performed with an Agilent 1200 Series liquid chromatographic system equipped with a G1315B diode-array detector (DAD, $240 \mathrm{~nm}$ ) (Agilent Technologies, Santa Clara, CA). A C18 column (Zorbax ${ }^{\circledR}$ SB-C18, $\left.4.6 * 150 \mathrm{~mm}, 5 \mu \mathrm{m}\right)$ (Agilent 
Technologies) combined with a guard column (SecurityGuard ${ }^{\mathrm{TM}}$ cartridge C18, $4.0 * 3.0 \mathrm{~mm}$ )

(Phenomenex) was used. The mobile phase consisted of $70 \%$ acetonitrile and $30 \%$ water $\left(\mathrm{v} \mathrm{v}^{-}\right.$ ${ }^{1}$ ), including $0.02 \%$ acetic acid (Merck). The water was purified with a Milli-Q ${ }^{\circledR}$ Plus system (Millipore Corporation, Burlington, MA). ChemStation ${ }^{\circledR}$ software was used for instrument control and data handling (Agilent Technologies).

To assure the quality of analyses, control soil samples were included in each extraction set. They had been treated with the fluazinam standard in the same manner as the samples used in the experiments but without incubation. To assess the repeatability of the results of the HPLC measurements, fluazinam standard solution $\left(10 \mathrm{mg} \mathrm{L}^{-1}\right)$ was measured several times in each HPLC run. The limit of detection (LOD) was $0.03 \mathrm{mg} \mathrm{kg}^{-1}$ and the limit of quantification (LOQ) $0.1 \mathrm{mg} \mathrm{kg}^{-1}$.

\section{Calculations and statistical analyses}

DT50 is the time required for the concentration to decline to half of its initial value. Estimated DT50s for the follow-up and annual climatic rotation experiments were calculated from the results after 1 year of incubation by using Equation 1:

$\mathrm{DT} 50=\mathrm{t} * \ln (2) / \ln \left(\mathrm{N}_{0} / \mathrm{N}_{\mathrm{t}}\right)$

where $\mathrm{t}=$ incubation time, i.e. 360 days, $\mathrm{N}_{0}=$ concentration of fluazinam at the beginning of the experiment $\left(\mathrm{mg} \mathrm{kg}^{-1}\right)$ and $\mathrm{N}_{\mathrm{t}}=$ concentration of fluazinam after 360 days $\left(\mathrm{mg} \mathrm{kg}^{-1}\right)$. 
The results of the Shirlan ${ }^{\circledR}$-sprayed samples of the follow-up experiment were used in a 4factor design. First, the mean concentration was calculated from triplicates and then the dependent variable was constructed by calculating the percentage reduction in fluazinam for each incubation period (0-90, 90-180, 180-270, and 270-360 days). The factors were sampling depth (0-20 cm and 20-35 cm), soil water content (moist and waterlogged), temperature $\left(5^{\circ} \mathrm{C}\right.$ and $\left.22^{\circ} \mathrm{C}\right)$, and duration of incubation $(90,180,270$, and 360 days). The normality of the results was graphically checked with quantile-quantile (Q-Q) plots, as well as using the Shapiro-Wilk test. The level of statistical significance $(p)$ was taken to be 0.05 . Data management and statistical analyses were performed with SPSS Statistics 21 (IBM Corporation, Armonk, NY).

\section{Results}

\section{Follow-up experiment}

In the follow-up experiment (Table 2), after 1 year, a prominent amount of added fluazinam was recovered in topsoil and in subsoil, ranging from $54-70 \%$ and $67-74 \%$, respectively. After 1 year of incubation for fluazinam in $\operatorname{Shirlan}^{\circledR}$, the average recovery was higher in subsoil $(73 \%)$ than in topsoil $(64 \%)$, the recovery in moist soil $(69 \%)$ being similar to that in waterlogged soil $(68 \%)$, while the recovery at $5^{\circ} \mathrm{C}(71 \%)$ was higher than that at $22^{\circ} \mathrm{C}(66 \%)$. Accordingly, the average recovery of the fluazinam standard was higher in subsoil (69\%) than in topsoil (58\%). In moist soil (64\%) it was similar to that in waterlogged soil (63\%), but slightly higher at $5^{\circ} \mathrm{C}(65 \%)$ than at $22^{\circ} \mathrm{C}(62 \%)$. Somewhat more fluazinam in Shirlan ${ }^{\circledR}$ was recovered than fluazinam in the pure chemical form, the respective recoveries being $68 \%$ and $63 \%$. After 1 year, the highest recovery was recorded in the moist subsoil at $5^{\circ} \mathrm{C}$ in the 
Shirlan ${ }^{\circledR}$ treatment and the lowest one in the fluazinam standard treatment in waterlogged topsoil at $22^{\circ} \mathrm{C}$. The loss of the fluazinam standard in topsoil is illustrated in Figure 3 and that of Shirlan ${ }^{\circledR}$ in Figure 4. The degradation of fluazinam ( 0 days, 180 days, and 360 days) in the Shirlan ${ }^{\circledR}$ treated topsoil sample (moist, $22^{\circ} \mathrm{C}$ ) in the follow-up experiment is illustrated in the chromatograms in Figure 5.

For Shirlan ${ }^{\circledR}$, the percentage reduction in the fluazinam concentration in consecutive 90 -day periods was generally greater during the first 90 incubation days, ranging from $15-26 \%$, whereafter it drastically declined (Table 3). However, in the soils sprayed with the fluazinam standard, the situation was much more variable. In general, the percentage reduction was greater during the incubation period from 270 to 360 days, being $13-23 \%$, than in the previous periods (0-90, 90-180, and 180-270 days), being 1-19\%. For Shirlan ${ }^{\circledR}$, the concentration reduction during the incubation period from 270 to 360 days was only $0-6 \%$.

The estimated DT50s for the fluazinam standard varied from 418-548 days for topsoil and 629-713 days for subsoil, while the corresponding figures for Shirlan ${ }^{\circledR}$ were 472-704 days and 719-833 days, respectively (Table 4). The estimated DT50 in subsoil was on average 201 days longer than in topsoil. At $5^{\circ} \mathrm{C}$, the estimated DT50 was on average 79 days longer than at $22^{\circ} \mathrm{C}$, while in the Shirlan ${ }^{\circledR}$ treatment it was 112 days longer than in the fluazinam standard treatment.

\section{Annual climatic rotation experiment}

In the annual climatic rotation experiment, the residual concentrations were also high after 1 year of incubation (Table 5). The estimated DT50 was 436 days in topsoil and 575 days in 
subsoil for the soils treated with fluazinam standard, and 355 and 583 days, respectively, for the soils treated with Shilan ${ }^{\circledR}$. Generally, the fluazinam concentration diminished most rapidly under moist summer conditions, i.e. during the first part of the experiment. Under spring conditions (the last part of the experiment), which were similar to autumn conditions, the degradation was very slow, in some cases even negligible. It is noteworthy, however, that the degradation of fluazinam was recorded to continue under winter conditions.

The loss of fluazinam was faster in topsoil than in subsoil, its recovery being $56 \%$ in the standard-treated and $50 \%$ in Shirlan ${ }^{\circledR}$-treated samples. In subsoil, the recovery of fluazinam was similar, being $65 \%$ in the standard-treated samples and $66 \%$ in Shirlan ${ }^{\circledR}$-treated ones. Generally, the loss of fluazinam was most rapid during the first 90 days of the experiment, slowing down considerably during each subsequent 90-day period. After 1 year of incubation, the highest recovery was recorded in Shirlan ${ }^{\circledR}$-treated subsoil and the lowest in Shirlan ${ }^{\circledR}$ treated topsoil, the respective figures being $66 \%$ and $50 \%$.

\section{SOM experiment}

The presence of SOM clearly enhanced the loss of fluazinam (Table 6). In the samples containing SOM, the reduction was $14-34 \%$ greater than in those from which SOM had been removed. When fluazinam was added in the standard solution, its recovery was similar in both the topsoil and subsoil samples. However, when it was added in Shirlan ${ }^{\circledR}$, the soil samples differed markedly in their responses, the recovery in topsoil being lower than in subsoil.

\section{Field samples}


From the total of 30 samples collected from fields that had been under intensive potato cultivation, fluazinam was detected in 17 , the concentrations being $0.14-1.15 \mathrm{mg} \mathrm{kg}^{-1}$ (Table 7). Among the samples containing fluazinam, 14 had been sprayed with Shirlan ${ }^{\circledR}$ during the same growing season. Fluazinam was also found in three fields that had not been sprayed in the same growing season. Out of the 13 samples in which fluazinam was not detected, six were collected from fields sprayed with Shirlan ${ }^{\circledR}$ and seven from those not sprayed with Shirlan ${ }^{\circledR}$ during the same growing season.

In the majority of the samples in which fluazinam was detected, its concentration was $0.14-$ $0.37 \mathrm{mg} \mathrm{kg}^{-1}$. The highest concentration $\left(1.15 \mathrm{mg} \mathrm{kg}^{-1}\right)$ was recorded in sample A2, which was sprayed three times during the same growing season. Samples H1-H6 were collected from fields that had been under intensive cultivation for about 50 years and frequently sprayed with Shirlan ${ }^{\circledR}$. From these fields, fluazinam was detected in four samples (H3-H6) at concentrations of $0.14-0.26 \mathrm{mg} \mathrm{kg}^{-1}$.

In samples $\mathrm{Y} 1$ and $\mathrm{Y} 3$, fluazinam concentrations of 0.15 and $0.20 \mathrm{mg} \mathrm{kg}^{-1}$, respectively, were detected, even though the fields had not been sprayed during the same growing season. Interestingly, fluazinam was not detected in the corresponding sample Y2. Samples E1 and E2 were from potato fields with a history of Shirlan ${ }^{\circledR}$ spraying until 2011. However, fluazinam was not detected from these fields, while a field treated similarly (P1) had a fluazinam concentration of $0.14 \mathrm{mg} \mathrm{kg}^{-1}$.

In two fields sprayed six times during the same growing season (P2 and P6), no fluazinam was detected from the soil samples. In four other similar samples (P3, P4, P5, and P7), the 
concentrations were $0.33-0.53 \mathrm{mg} \mathrm{kg}^{-1}$. Fluazinam was not detected in the organic soils T3 and T4, despite field T4 having been sprayed during the same growing season.

The control soil samples and HPLC repeatability samples confirmed the uniform quality of the analyses throughout the experiments. Figure 6 presents the HPLC chromatogram of a repeatability sample (fluazinam standard $10 \mathrm{mg} \mathrm{L}^{-1}$ ).

\section{Factorial design}

The factorial design demonstrated that the sampling depth and the duration of incubation had the main effects, i.e. they significantly affected the fluazinam concentration, excluding the effects of all other factors. Interactions were found between the sampling depth and duration of incubation, the soil water content and duration of incubation, and the temperature and duration of incubation. In other words, for the samples sprayed with Shirlan ${ }^{\circledR}$ in the follow-up experiment, the factorial design demonstrated that the percentage reduction in fluazinam over time significantly differed between topsoil and subsoil, moist and waterlogged soil, and temperatures of $5^{\circ} \mathrm{C}$ and $22^{\circ} \mathrm{C}$. In our experiment this meant that fluazinam degradation was enhanced by the abundance of SOM, waterlogging, and a warmer temperature.

\section{Discussion}

In the follow-up treatment, the decline in the fluazinam concentration during each 90-day period was taken to indicate the rate of degradation. In Shirlan ${ }^{\circledR}$ treatment, the loss of fluazinam was most rapid at the very beginning of the experiment. For the fluazinam standard, the concentration decreased in a less consistent manner. During the final incubation 
period (270-360 days), its reduction rate in both topsoil and subsoil was quite high compared with the previous periods. Recently, Ren et al. ${ }^{[28]}$ reported for some recalcitrant pesticides that microbial adaptation can enhance their dissipation over time, but it is unknown whether this is valid for fluazinam. The unknown inert ingredients in the Shirlan ${ }^{\circledR}$-treated samples probably promoted the water solubility of fluazinam and thus enhanced its degradation at the beginning of the experiment.

Fluazinam is known to degrade more rapidly under anaerobic than aerobic conditions. ${ }^{[10]}$ Our follow-up experiment demonstrated that within a time scale of 1 year, waterlogging tended to enhance the degradation only slightly as compared with that under moist conditions. Although the formation of anaerobic conditions will be retarded at a low temperature such as $5^{\circ} \mathrm{C}$, such conditions can form at $22^{\circ} \mathrm{C}$, at least in the topsoil, where a high SOM content favors microbiological activity. Because the samples were not stirred during the experiments, a significant supply of oxygen did not occur.

In comparison with the values reported in the literature, the estimated DT50s in our follow-up experiment were consistently much longer. This is attributable to factors such as differences in the soil types, the temperature, and the light conditions (the samples in this study were incubated in darkness), differences in the added amount of fluazinam, and the analytical methods. Under waterlogged conditions, the estimated DT50s were generally shorter than under moist conditions, as concluded by EFSA. ${ }^{[10]}$

In the annual climatic rotation experiment, a prominent amount of fluazinam was still present in soil after 1 year. The loss of fluazinam was most rapid at the beginning of the experiment (mimicking moist summer conditions). It clearly slowed down as the experiment proceeded, 
being almost negligible in the last 90 -day period (spring). In Finland, soil microbial activity is low during winter, but in our experiment, some loss of fluazinam still occurred. Degradation was more prominent in topsoil high in SOM than in subsoil, because SOM favors microbial degradation. ${ }^{[14]}$ The estimated DT50s (355-583 days) were generally shorter than those in the follow-up experiment (418-833 days), in which the samples were kept under constant conditions for 1 year. This outcome could have been attributed to the freezing and thawing processes, which altered the soil structure. In this experiment, the estimated DT50s were also considerably longer than those reported in the literature.

The experiment on the impact of SOM removal clearly demonstrated that the SOM content considerably contributes to the degradation rate of fluazinam. In the samples without SOM removal, the degradation of fluazinam was more rapid, obviously due to the enhanced microbial activity. The degradation-promoting effect of SOM was especially marked in topsoil. Although the subsoil was innately low in SOM, the treatment with $\mathrm{H}_{2} \mathrm{O}_{2}$ nevertheless reduced the loss of fluazinam. The abundance of SOM appeared to particularly enhance the loss of fluazinam in Shirlan ${ }^{\circledR}$, probably because its water solubility was higher than that in the fluazinam standard.

In the fluazinam-containing soil samples collected from the potato fields, its concentrations were rather variable. Fluazinam was found in three samples from fields that had not been sprayed with Shirlan ${ }^{\circledR}$ in the same growing season. This indicates that fluazinam in soil can be carried over from one growing season to the next. Even though some fields had been sprayed with Shirlan ${ }^{\circledR}$ six times in the same growing season, the highest fluazinam concentration was recorded in a sample from a field that was sprayed three times during the same growing 
season. Three of the intensively cultivated potato fields had been sprayed frequently with Shirlan ${ }^{\circledR}$ for years until 2011, but in 2013, fluazinam was only detected in one of them.

On the other hand, fluazinam was not found in six samples from fields on which Shirlan ${ }^{\circledR}$ had been sprayed in the same growing season. Some of the samples were collected from fields that had been under intensive potato cultivation for decades and frequently sprayed with Shirlan ${ }^{\circledR}$. Despite this, not all of these samples contained fluazinam. In three samples, fluazinam was not found even though the fields had been sprayed with Shirlan ${ }^{\circledR}$ three times per growing season during the current and the two previous growing seasons. Our previous finding ${ }^{[27]}$ that fluazinam molecules were immobile and remained where they ended up with the incorporated potato tops is also valid for the potato field samples. Fluazinam was not found in the organic soil samples, probably because microbes had degraded it.

The sorption of pesticides onto soil particles can increase with a prolonged residence time. This phenomenon (aging) is due to pesticide diffusion to less accessible or stronger sorption sites, or both. ${ }^{[25]}$ Sharer et al. ${ }^{[29]}$ observed that as for pesticides with strong retention, little or no increase in sorption occurred with prolonged equilibration times. Therefore, most probably, the reduction in the fluazinam concentration in our experiments was mainly due to its degradation.

\section{Conclusions}

Despite some inconsistencies in the degradation rate, the main outcome was that a substantial amount of fluazinam remained in soil after 1 year of incubation. Our experiment 
demonstrated that this chemical can be quite persistent in soil, raising a concern about its accumulation in soil upon repeated applications.

In the follow-up and the annual climatic rotation experiment, more than half of the added fluazinam was still present in the samples after 1 year. The estimated DT50s were much longer than the corresponding values reported in the literature, and this trend was seen throughout the experiments. Fluazinam degradation in topsoil appeared to be more rapid than in subsoil due to the higher SOM content favoring microbial activity.

The results of the potato field samples were quite variable when considering the spraying history of the fields. There seemed to be no relationship between how long and how many times the fields had been sprayed with Shirlan ${ }^{\circledR}$ and the amount of fluazinam detected in the soil. Because of the uneven distribution of the pesticide, a large number of samples should be collected from the fields and the analysis should be carried out with several replicates to obtain a comprehensive picture of fluazinam degradation.

Based on the results obtained in all the experiments and from field soil samples, in professional potato production based on monoculture, fluazinam can be carried over to the next growing season in the field, especially under the cold conditions typical in Finland. Despite this, field soil samples indicated no substantial accumulation of the pesticide in soil.

Our experiments call for local soil and climate conditions to be taken into account in estimating the behavior of chemicals. The results highlight the risk of directly transferring information from different climates when formulating regulations for pesticide use. Further 
studies on the effect of photodegradation on the dissipation of fluazinam are needed to provide information on its fate in agricultural soils.

\section{Acknowledgments}

Mr. Miikka Olin (University of Helsinki) is acknowledged for his technical support in the use of HPLC, Mr. Hannu Rita for his participation in statistical analyses, and Mr. Jussi Tuomisto (Potato Research Institute) and the participating farmers for their support in potato field soil sampling. This work was supported by the Maj and Tor Nessling Foundation (Grant number 2012281), the August Johannes and Aino Tiura Foundation of Agricultural Research (Grant number 566), the Oiva Kuusisto Foundation, Maa- ja vesitekniikan tuki ry, the Finnish Concordia Fund, the Future Fund of the University of Helsinki, and the Forestry Fund of the University of Helsinki.

\section{References}

[1] Statistics Finland. Statistical Yearbook of Finland 2015; Statistics Finland: Helsinki, Finland, 2015. http://www.stat.fi/tup/julkaisut/tiedostot/julkaisuluettelo/yyti_stv_201500_2015_12602_net.p df (accessed June 16, 2016).

[2] Statistics Finland. Statistical Yearbook of Finland 2016; Statistics Finland: Helsinki, Finland, 2016.

http://www.stat.fi/tup/julkaisut/tiedostot/julkaisuluettelo/yyti_stv_201600_2016_16179_net_p 2.pdf (accessed June 27, 2017). 
[3] Trout, C.L.; Ristaino, J.B.; Madritch, M.; Wangsomboondee, T. Rapid detection of Phytophthora infestans in late blight-infected potato and tomato using PCR. Plant Dis. 1997, 81(9), 1042-1048.

[4] Environmental Protection Agency. Problem Formulation, for Ecological Risk Assessment, for Fluazinam (No EPA-HQ-OPP-2009-0039-0002); United States Environmental Protection Agency: Washington, DC, 2009.

[5] Health Canada. Registration Decision - Fluazinam (RD2008-09); Health Canada Pest Management Regulatory Agency: Ottawa, Ontario, 2008.

[6] Niemi, M.; Heiskanen, I.; Ahtiainen, J.; Laatikainen, T.; Rahkonen, A.; Ruuttunen, P. Impacts of pesticides on soil microorganisms and their activities. In Environmental risks of long-term pesticide use in potato cultivation; Ruuttunen, P., Laitinen, P., Eds.; MTT Agrifood Research Finland: Jokioinen, Finland, 2008; 121-150.

[7] Räsänen, K.; Mattila, T.; Porvari, P.; Kurppa, S.; Tiilikkala, K. Estimating the development of ecotoxicological pressure on water systems from pesticides in Finland 20002011. J. Cleaner Prod. 2014, 89, 65-77.

[8] Niemi, R.M.; Heiskanen, I.; Ahtiainen, J.H.; Rahkonen, A.; Mäntykoski, K.; Welling, I.; Laitinen, P.; Ruuttunen, P. Microbial toxicity and impacts on soil enzyme activities of pesticides used in potato cultivation. Appl. Soil Ecol. 2009, 41, 293-304. 
[9] Autio, S.; Mecke, M. Risk assessment of pesticides used consecutively in potato cultivaton. In Environmental risks of long-term pesticide use in potato cultivation; Ruuttunen, P., Laitinen, P., Eds.; MTT Agrifood Research Finland: Jokioinen, Finland, 2008; 151-177.

[10] European Food Safety Authority (EFSA). Conclusion on the peer review of fluazinam; Scientific Report 137; EFSA: Parma, Italy, 2008.

[11] Health Canada. Regulatory Note - Fluazinam (REG2003-12); Health Canada Pest Management Regulatory Agency: Ottawa, Ontario, 2003.

[12] Hu, W.; Lee, S.J.; Kim, J.-E. Adsorption-desorption, leaching, and degradation pattern of fungicide fluazinam in the soil environment. Han'guk Nonghwa Hakhoechi 1997, 40(2), 128133.

[13] Dong, F.-s.; Yang, S.; Liu, X.-g.; Sun, J.-p.; Zheng, Y.-q.; Li, C.-j.; Yao, J.-r. Fate of fluazinam in pepper and soil after application. Agric. Sci. China 2008, 7(2), 193-199.

[14] Laitinen, P.; Lejonqvist, M.; Rämö, S.; Welling, L.; Ojanen, H.; Hannukkala, A. Use of pesticides in starch and chip potato production; Pub. No. 81, series A; MTT Agrifood Research Finland: Jokioinen, Finland, 2000. http://jukuri.luke.fi/bitstream/handle/10024/440060/asarja81.pdf?sequence=1\&isAllowed=y (accessed September 8, 2019).

[15] La Poe, R.G. Sorption and desorption of volatile chlorinated aliphatic compounds by soil and soil components. Ph.D. Thesis, Cornell University, Ithaca, NY, 1985. 
[16] Ruuttunen, P.; Laitinen, P.; Rahkonen, A.; Alakukku, L.; Welling, L.; Mäntykoski, K. Pesticide residues in potato fields - field trials. In Environmental risks of long-term pesticide use in potato cultivation; Ruuttunen, P., Laitinen, P., Eds.; MTT Agrifood Research Finland: Jokioinen, Finland, 2008; 26-69.

[17] Ministry of Water and Environment. Pronouncement of the environmental impact of pesticide Shirlan; Ministry of Water and Environment, Helsinki, Finland, 1994.

[18] Baun, A.; Ledin, A.; Reitzel, L.A.; Bjerg, P.L.; Christensen, T.H. Xenobiotic organic compounds in leachates from the Danish MSW landfills - chemical analysis and toxicity tests. Water Res. 2004, 38, 3845-3858.

[19] Heikinheimo, M.; Fougstedt, B. Statistics of soil temperature in Finland 1971-1990; Finnish Meteorological Institute: Helsinki, Finland, 1992.

[20] Andersson, M.; Hartikainen, H. 2008. Effect of freezing and thawing on behavior of pesticides in soil. In Environmental risks of long-term pesticide use in potato cultivation; Ruuttunen, P., Laitinen, P., Eds.; MTT Agrifood Research Finland: Jokioinen, Finland, 2008; $81-92$.

[21] Finnish Meteorological Institute. Atmosphere-ABC. https://ilmatieteenlaitos.fi/ilmakehaabc/Kasvukausi (accessed September 22, 2018). 
[22] Hannukkala, A.O.; Kaukoranta, T.; Lehtinen, A.; Rahkonen, A. Late-blight epidemics on potato in Finland, 1933-2002; increased and earlier occurrence of epidemics associated with climate change and lack of rotation. Plant Pathol. 2007, 56, 167-176.

[23] Food and Agriculture Organization of the United Nations (FAO). World Reference Base for Soil Resources 2014. In World Soil Resources Reports; Pub. No. 106; FAO: Rome, Italy, 2015. http://www.fao.org/3/i3794en/I3794en.pdf (accessed October 15, 2015).

[24] Brinch, U.C.; Ekelund, F.; Jacobsen, C.S. Method for spiking soil samples with organic compounds. Appl. Environ. Microbiol. 2002, 68(4), 1808-1816.

[25] Koskinen, W.C.; Cox, L.; Yen, P.Y. Changes in sorption/bioavailability of imidacloprid metabolites in soil with incubation time. Biol. Fertil. Soils 2002, 33, 546-550.

[26] Kunze, G.W.; Dixon, J.B. Removal of Organic Matter. In Methods of Soil Analysis. Part 1-Physical and Mineralogical Methods, 2nd ed.; Klute, A., Ed.; Soil Science Society of America: Madison, WI, 1986; 95-97.

[27] Hakala, K.P.; Tuomainen, P.M.; Yli-Halla, M.J.; Hartikainen, H. High-performance liquid chromatography (HPLC) as a tool for monitoring the fate of fluazinam in soil. J. Environ. Sci. Health, Part B 2014, 49, 491-497.

[28] Ren, X.; Zeng, G.; Tang, L.; Wang, J.; Wan, J.; Liu, Y.; Yu, J.; Yi, H.; Ye, S.; Deng, R. Sorption, transport and biodegradation - An insight into bioavailability of persistent organic pollutants in soil. Sci. Total Environ. 2018, 610-611, 1154-1163. 
[29] Sharer, M.; Park, J.-H.; Voice, T.C.; Boyd, S.A. Aging effects on the sorption-desorption characteristics of anthropogenic organic compounds in soil. J. Environ. Qual. 2003, 32, 13851392.

\section{FIGURE CAPTIONS}

Figure 1. Fluazinam molecule. 
Figure 2. Soil sampling locations.

Figure 3. Degradation of fluazinam in topsoil $\left(\mathrm{mg} \mathrm{kg}^{-1}\right)$ following treatment with fluazinam standard in the follow-up experiment (with standard deviation bars in one direction, being 0$10 \mathrm{mg} \mathrm{kg}^{-1}$ ): a moist soil at $22^{\circ} \mathrm{C}, \mathbf{b}$ waterlogged soil at $22^{\circ} \mathrm{C}, \mathbf{c}$ moist soil at $5^{\circ} \mathrm{C}$, and $\mathbf{d}$ waterlogged soil at $5^{\circ} \mathrm{C}$.

Figure 4. Degradation of fluazinam in topsoil $\left(\mathrm{mg} \mathrm{kg}^{-1}\right)$ following Shirlan ${ }^{\circledR}$ treatment in the follow-up experiment (with standard deviation bars in one direction, being 1-7 $\mathrm{mg} \mathrm{kg}^{-1}$ ): $\mathbf{a}$ moist soil at $22^{\circ} \mathrm{C}, \mathbf{b}$ waterlogged soil at $22^{\circ} \mathrm{C}$, $\mathbf{c}$ moist soil at $5^{\circ} \mathrm{C}$, and $\mathbf{d}$ waterlogged soil at $5^{\circ} \mathrm{C}$

Figure 5. HPLC chromatograms illustrating the degradation of fluazinam in the Shirlan ${ }^{\circledR}$ treated topsoil sample (moist, $22^{\circ} \mathrm{C}$ ) in the follow-up experiment: a 0 days, b 180 days, and $\mathbf{c}$ 360 days.

Figure 6. HPLC chromatogram of a repeatability sample (fluazinam standard $10 \mathrm{mg} \mathrm{L}^{-1}$ ). 




Fig. 1

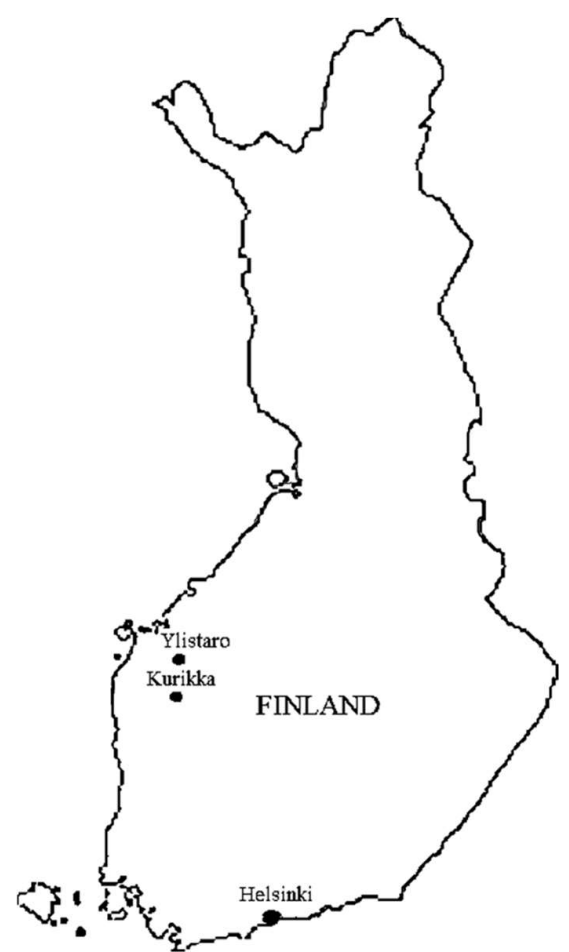

Fig. 2 

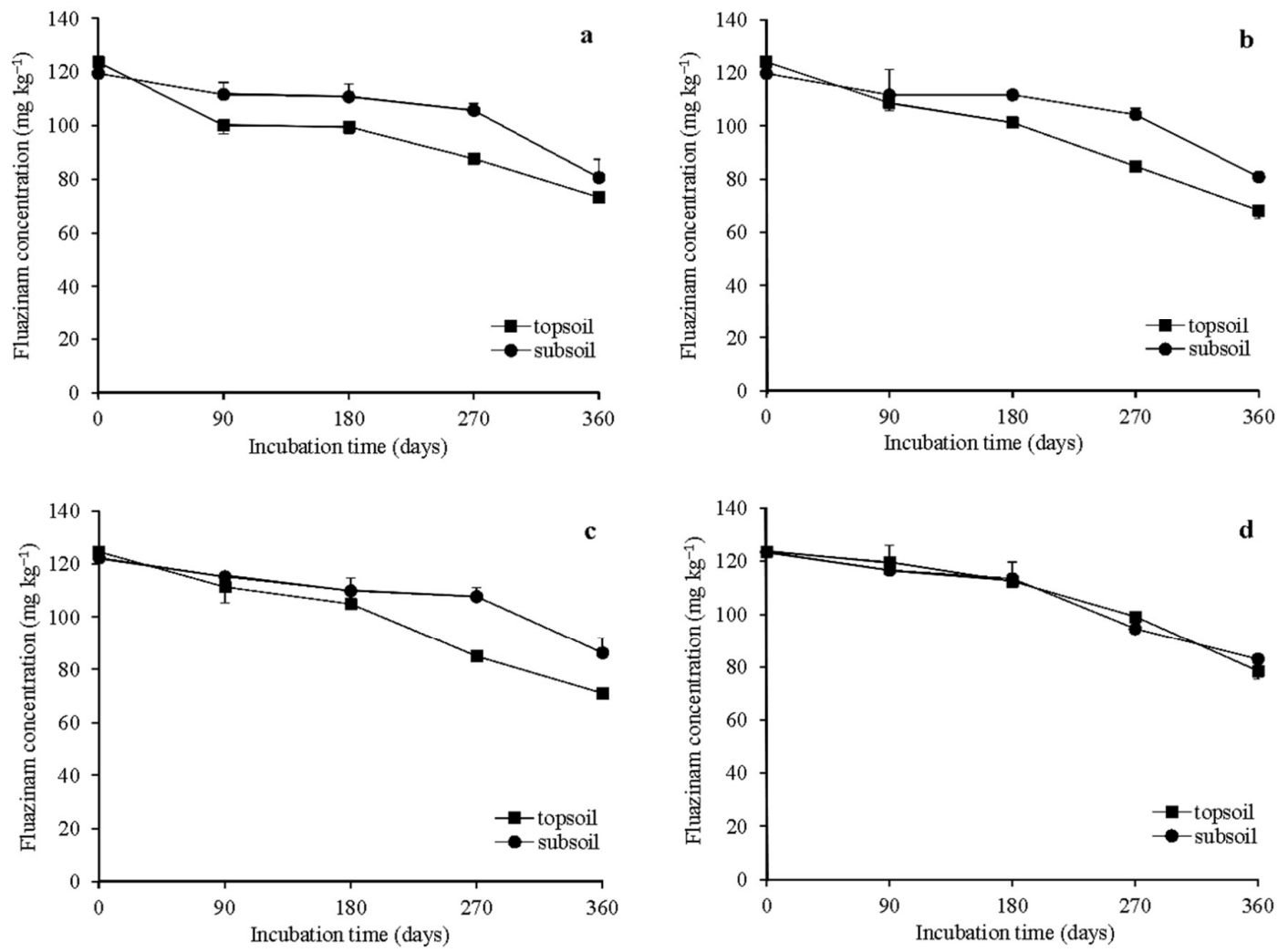

Fig. 3 

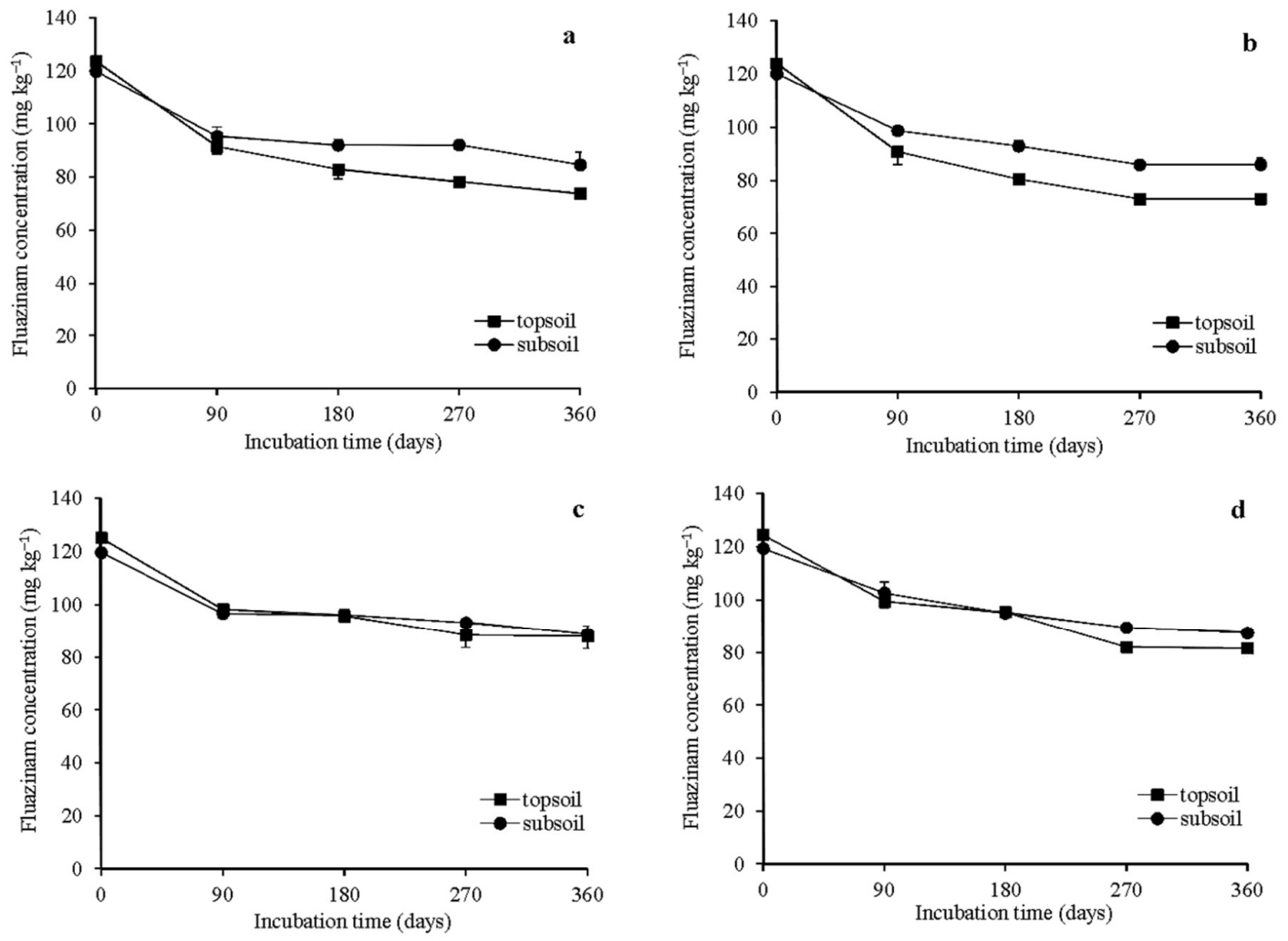

Fig. 4 

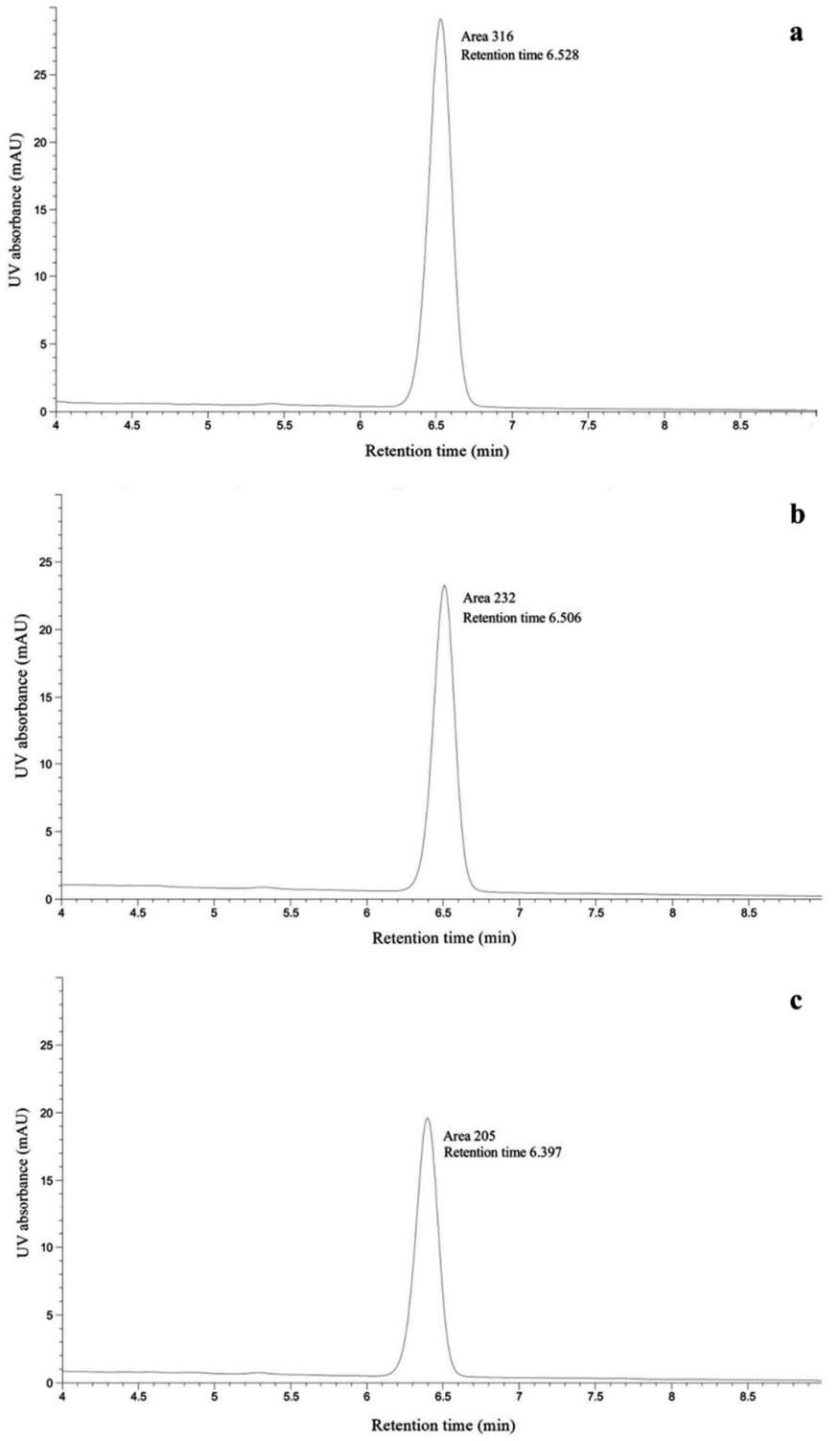

Fig. 5 


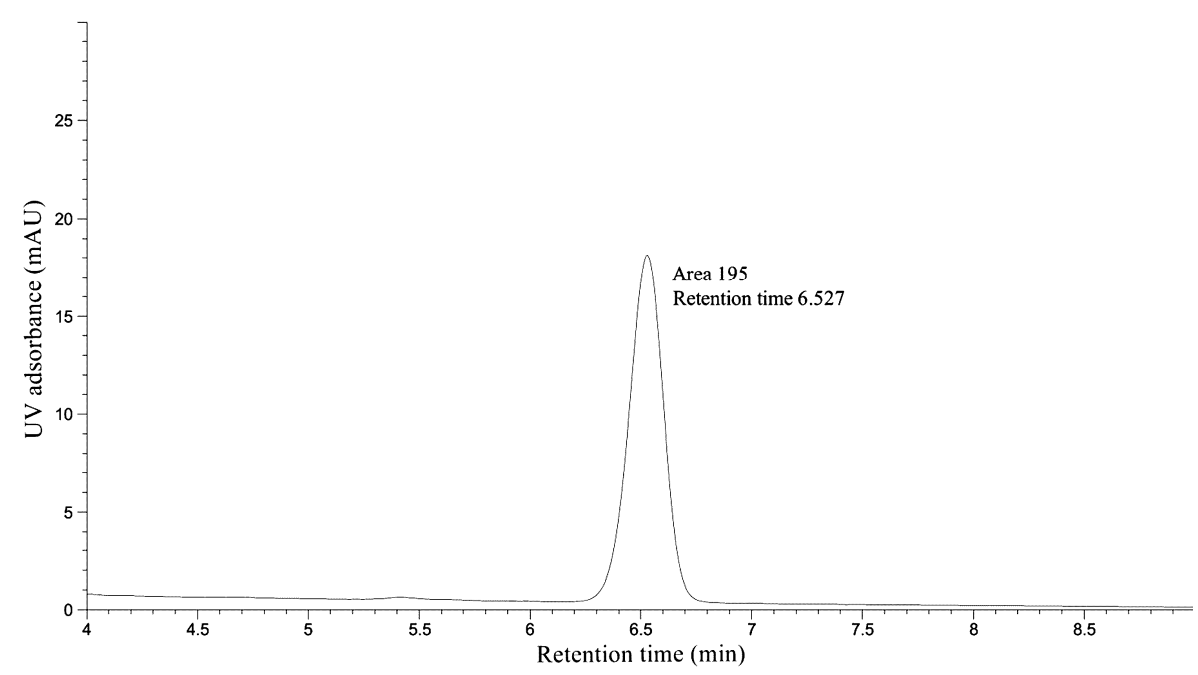

Fig. 6

Table 1. Soil properties and their standard deviations at the Viikki research farm of the University of Helsinki.

\begin{tabular}{|c|c|c|c|c|c|c|c|c|}
\hline \multirow[b]{2}{*}{ Soil } & \multicolumn{2}{|c|}{$\mathrm{pH}^{1}$} & \multicolumn{2}{|c|}{$\mathrm{CEC}_{\text {pot }}{ }^{2}$} & \multicolumn{2}{|c|}{ SOM } & \multicolumn{2}{|c|}{ Sand $^{3}$} \\
\hline & & $\mathrm{SD}$ & $\left(\operatorname{cmol}(+) \mathrm{kg}^{-1}\right)$ & $\mathrm{SD}$ & $(\%)$ & $\mathrm{SD}$ & $(\%)$ & $\mathrm{SD}$ \\
\hline Topsoil & 5.6 & 0.0 & 9.4 & 0.5 & 2.4 & 0.0 & 92 & 0 \\
\hline Subsoil & 5.4 & 0.0 & 3.7 & 0.3 & 0.3 & 0.0 & 98 & 0 \\
\hline
\end{tabular}

${ }^{1} \mathrm{pH}$ in $0.01 \mathrm{M} \mathrm{CaCl}_{2}(1: 2.5)$.

${ }^{2} \mathrm{CEC}_{\text {pot }}$, potential cation-exchange capacity, determined with $1 \mathrm{M} \mathrm{CH}_{3} \mathrm{COONH}_{4}, \mathrm{pH} 7.0$.

${ }^{3}$ Sand $(0.06-2 \mathrm{~mm})$ content of the soil, dominated by medium sand $(0.2-0.6 \mathrm{~mm})$.

Table 2. Percentage recovery and standard deviation (\%) of added fluazinam after 90, 180, 270 , and 360 days of incubation $(n=3)$ in the follow-up experiment.

\begin{tabular}{|c|c|c|c|c|c|c|c|c|c|c|}
\hline & \multirow[b]{2}{*}{$\begin{array}{c}\text { Water } \\
\text { content }\end{array}$} & \multirow[b]{2}{*}{$\begin{array}{c}\mathrm{T} \\
\left({ }^{\circ} \mathrm{C}\right)\end{array}$} & \multicolumn{4}{|c|}{ Recovery (\%) } & \multicolumn{4}{|c|}{$\mathrm{SD}(\%)$} \\
\hline & & & $90 \mathrm{~d}$ & $180 \mathrm{~d}$ & $270 \mathrm{~d}$ & $360 \mathrm{~d}$ & $90 \mathrm{~d}$ & $180 \mathrm{~d}$ & $270 \mathrm{~d}$ & $360 \mathrm{~d}$ \\
\hline \multicolumn{11}{|l|}{ Topsoil } \\
\hline \multirow[t]{4}{*}{$\begin{array}{l}\text { Fluazinam } \\
\text { standard }\end{array}$} & Moist & 22 & 81 & 80 & 71 & 59 & 3 & 3 & 1 & 1 \\
\hline & & 5 & 90 & 83 & 68 & 57 & 5 & 1 & 1 & 2 \\
\hline & Waterlogged & 22 & 86 & 83 & 68 & 54 & 2 & 2 & 2 & 3 \\
\hline & & 5 & 96 & 92 & 80 & 63 & 2 & 3 & 2 & 1 \\
\hline
\end{tabular}




\begin{tabular}{|c|c|c|c|c|c|c|c|c|c|}
\hline \multirow[t]{4}{*}{ Shirlan $^{\circledR}$} & \multirow[t]{2}{*}{ Moist } & 22 & 74 & 67 & 63 & 60 & 2 & 3 & 2 \\
\hline & & 5 & 80 & 76 & 71 & 70 & 1 & 2 & 4 \\
\hline & \multirow[t]{2}{*}{ Waterlogged } & 22 & 74 & 64 & 59 & 59 & 4 & 2 & 2 \\
\hline & & 5 & 81 & 76 & 66 & 66 & 4 & & 2 \\
\hline
\end{tabular}

Subsoil

\begin{tabular}{cccccccccccc}
$\begin{array}{c}\text { Fluazinam } \\
\text { standard }\end{array}$ & Moist & 22 & 94 & 92 & 87 & 67 & 5 & 4 & 6 & 1 \\
& & 5 & 96 & 95 & 90 & 71 & 2 & 5 & 5 & 2 \\
& Waterlogged & 22 & 94 & 93 & 87 & 67 & 8 & 1 & 1 & 3 \\
& & 5 & 97 & 96 & 79 & 69 & 9 & 6 & 2 & 2 \\
Shirlan $^{\circledR}$ & Moist & 22 & 80 & 77 & 76 & 71 & 3 & 2 & 1 & 4 \\
& & 5 & 81 & 80 & 77 & 74 & 1 & 1 & 1 & 3 \\
& \multirow{3}{*}{ Waterlogged } & 22 & 82 & 77 & 72 & 72 & 2 & 3 & 2 & 2 \\
& & 5 & 85 & 79 & 75 & 73 & 3 & 1 & 1 & 1 \\
\hline
\end{tabular}

Table 3. Percentage reduction in the fluazinam concentration in 90 days for successive incubation periods in the follow-up experiment.

\begin{tabular}{|c|c|c|c|c|c|c|}
\hline & \multirow[b]{2}{*}{$\begin{array}{c}\text { Water } \\
\text { content }\end{array}$} & \multirow[b]{2}{*}{$\begin{array}{c}\text { Temperature } \\
\left({ }^{\circ} \mathrm{C}\right) \\
\end{array}$} & \multicolumn{4}{|c|}{ Reduction (\%) } \\
\hline & & & $0-90 \mathrm{~d}$ & $90-180 \mathrm{~d}$ & $180-270 \mathrm{~d}$ & $270-360 \mathrm{~d}$ \\
\hline \multirow{5}{*}{$\begin{array}{l}\text { Topsoil } \\
\text { Fluazinam } \\
\text { standard }\end{array}$} & & & & & & \\
\hline & Moist & 22 & 19 & 2 & 11 & 17 \\
\hline & & 5 & 10 & 8 & 18 & 16 \\
\hline & Waterlogged & 22 & 14 & 3 & 18 & 21 \\
\hline & & 5 & 4 & 4 & 13 & 21 \\
\hline \multirow[t]{4}{*}{ Shirlan $^{\circledR}$} & Moist & 22 & 26 & 10 & 5 & 4 \\
\hline & & 5 & 20 & 4 & 7 & 2 \\
\hline & Waterlogged & 22 & 26 & 14 & 7 & 1 \\
\hline & & 5 & 19 & 6 & 13 & 1 \\
\hline \multirow{5}{*}{$\begin{array}{l}\text { Subsoil } \\
\text { Fluazinam } \\
\text { standard }\end{array}$} & & & & & & \\
\hline & Moist & 22 & 6 & 2 & 5 & 23 \\
\hline & & 5 & 4 & 1 & 5 & 21 \\
\hline & Waterlogged & 22 & 6 & 1 & 6 & 23 \\
\hline & & 5 & 3 & 1 & 18 & 13 \\
\hline \multirow[t]{4}{*}{ Shirlan $^{\circledR}$} & Moist & 22 & 20 & 4 & 1 & 6 \\
\hline & & 5 & 19 & 1 & 4 & 4 \\
\hline & Waterlogged & 22 & 18 & 6 & 6 & 0 \\
\hline & & 5 & 15 & 8 & 5 & 2 \\
\hline
\end{tabular}


Table 4. Estimated half-life (DT50) and standard deviation (days) $(n=3)$ in the follow-up experiment.

\begin{tabular}{|c|c|c|c|c|}
\hline & $\begin{array}{c}\text { Water } \\
\text { content }\end{array}$ & $\begin{array}{c}\text { Temperature } \\
\left({ }^{\circ} \mathrm{C}\right)\end{array}$ & $\begin{array}{l}\text { DT50 } \\
\text { (days) }\end{array}$ & $\begin{array}{c}\mathrm{SD} \\
\text { (days) }\end{array}$ \\
\hline \multirow{5}{*}{$\begin{array}{l}\text { Topsoil } \\
\text { Fluazinam } \\
\text { standard }\end{array}$} & & & & \\
\hline & Moist & 22 & 476 & 6 \\
\hline & & 5 & 443 & 30 \\
\hline & Waterlogged & 22 & 418 & 31 \\
\hline & & 5 & 548 & 49 \\
\hline \multirow[t]{4}{*}{ Shirlan $^{\circledR}$} & Moist & 22 & 485 & 21 \\
\hline & & 5 & 704 & 54 \\
\hline & Waterlogged & 22 & 472 & 11 \\
\hline & & 5 & 588 & 63 \\
\hline \multirow{5}{*}{$\begin{array}{l}\text { Subsoil } \\
\text { Fluazinam } \\
\text { standard }\end{array}$} & & & & \\
\hline & Moist & 22 & 633 & 69 \\
\hline & & 5 & 713 & 64 \\
\hline & Waterlogged & 22 & 634 & 17 \\
\hline & & 5 & 629 & 23 \\
\hline \multirow[t]{4}{*}{ Shirlan $^{\circledR}$} & Moist & 22 & 719 & 61 \\
\hline & & 5 & 833 & 48 \\
\hline & Waterlogged & 22 & 785 & 68 \\
\hline & & 5 & 800 & 44 \\
\hline
\end{tabular}

Table 5. Concentration $\left(\mathrm{mg} \mathrm{kg}^{-1}\right)$, standard deviation $\left(\mathrm{mg} \mathrm{kg}^{-1}\right)$, recovery $(\%)$, and percentage reduction of added fluazinam at the end of successive 90-day periods simulating the soil conditions during 1 year and estimated half-life (DT50) (days) $(n=3)$.

\begin{tabular}{|c|c|c|c|c|c|c|c|c|}
\hline & $\begin{array}{l}\text { Cumulative } \\
\text { duration (d) }\end{array}$ & $\begin{array}{c}\text { Water } \\
\text { content }\end{array}$ & $\begin{array}{c}\mathrm{T} \\
\left({ }^{\circ} \mathrm{C}\right) \\
\end{array}$ & $\begin{array}{c}\mathrm{c} \\
\left(\mathrm{mg} \mathrm{kg}^{-1}\right) \\
\end{array}$ & $\begin{array}{c}\mathrm{SD} \\
\left(\mathrm{mg} \mathrm{kg}^{-1}\right) \\
\end{array}$ & $\begin{array}{c}\text { Recovery } \\
(\%)\end{array}$ & $\begin{array}{c}\text { Reduction } \\
(\%)\end{array}$ & $\begin{array}{c}\text { DT50 } \\
\text { (d) }\end{array}$ \\
\hline \multicolumn{9}{|l|}{$\begin{array}{l}\text { Fluazinam } \\
\text { standard }\end{array}$} \\
\hline \multirow[t]{4}{*}{ Topsoil } & 90 & moist & 22 & 100 & 7 & 81 & 19 & \\
\hline & 180 & wet & 5 & 85 & 1 & 68 & 16 & \\
\hline & 270 & wet & -7 & 74 & 4 & 60 & 12 & \\
\hline & 360 & wet & 5 & 70 & 2 & 56 & 7 & 436 \\
\hline \multirow[t]{4}{*}{ Subsoil } & 90 & moist & 22 & 105 & 7 & 88 & 12 & \\
\hline & 180 & wet & 5 & 91 & 1 & 76 & 14 & \\
\hline & 270 & wet & -7 & 80 & 3 & 67 & 12 & \\
\hline & & & & 33 & & & & \\
\hline
\end{tabular}




$\begin{array}{llllllll}360 & \text { wet } & 5 & 77 & 2 & 65 & 3 & 575\end{array}$

Shirlan ${ }^{\circledR}$

$\begin{array}{lcccccccc}\text { Topsoil } & 90 & \text { moist } & 22 & 92 & 3 & 74 & 26 & \\ & 180 & \text { wet } & 5 & 75 & 1 & 60 & 19 & \\ & 270 & \text { wet } & -7 & 64 & 3 & 52 & 13 & \\ & 360 & \text { wet } & 5 & 61 & 2 & 50 & 4 & 355\end{array}$

\begin{tabular}{lcccccccc} 
Subsoil & 90 & moist & 22 & 95 & 3 & 80 & 20 & \\
& 180 & wet & 5 & 83 & 3 & 70 & 13 & \\
& 270 & wet & -7 & 81 & 4 & 67 & 4 & 583 \\
\hline
\end{tabular}

Table 6. Percentage recovery of fluazinam and standard deviation (\%) after 90 days of incubation with and without the removal of SOM $(n=3)$.

\begin{tabular}{|c|c|c|c|c|c|}
\hline & \multicolumn{2}{|c|}{ Recovery (\%) } & \multicolumn{2}{|c|}{$\mathrm{SD}(\%)$} & \multirow[b]{2}{*}{$\begin{array}{c}\text { SOM } \\
\text { efficiency }^{1}\end{array}$} \\
\hline & $\begin{array}{c}\text { SOM } \\
\text { removed }\end{array}$ & $\begin{array}{c}\text { SOM } \\
\text { present }\end{array}$ & $\begin{array}{c}\text { SOM } \\
\text { removed }\end{array}$ & $\begin{array}{c}\text { SOM } \\
\text { present }\end{array}$ & \\
\hline \multicolumn{6}{|l|}{ Topsoil } \\
\hline $\begin{array}{c}\text { Fluazinam } \\
\text { standard }\end{array}$ & 83 & 69 & 3 & 4 & 16 \\
\hline Shirlan $^{\circledR}$ & 80 & 53 & 4 & 2 & 34 \\
\hline \multicolumn{6}{|l|}{ Subsoil } \\
\hline $\begin{array}{c}\text { Fluazinam } \\
\text { standard }\end{array}$ & 84 & 73 & 3 & 0 & 14 \\
\hline Shirlan ${ }^{\circledR}$ & 88 & 70 & 7 & 6 & 21 \\
\hline
\end{tabular}

Table 7. Properties, concentration of fluazinam $\left(\mathrm{mg} \mathrm{kg}^{-1}\right)$, standard deviation $\left(\mathrm{mg} \mathrm{kg}^{-1}\right)(n=$ 3), and number of sprayings of field soil samples.

\begin{tabular}{|c|c|c|c|c|c|c|c|c|}
\hline \multirow[b]{2}{*}{$\begin{array}{l}\text { Soil } \\
\text { code }\end{array}$} & \multirow[b]{2}{*}{$\begin{array}{l}\text { Soil } \\
\text { type }\end{array}$} & \multirow[b]{2}{*}{$\mathrm{pH}^{1}$} & \multirow[b]{2}{*}{$\begin{array}{l}\text { SOM } \\
(\%)\end{array}$} & \multirow[b]{2}{*}{$\begin{array}{l}\text { Concentration }{ }^{2} \\
\left(\mathrm{mg} \mathrm{kg}^{-1}\right)\end{array}$} & \multirow[b]{2}{*}{$\begin{array}{c}\mathrm{SD} \\
(\underset{\mathrm{mg} \mathrm{kg}}{1})\end{array}$} & \multicolumn{3}{|c|}{ Number of sprayings ${ }^{3}$} \\
\hline & & & & & & 2011 & 2012 & 2013 \\
\hline
\end{tabular}




\begin{tabular}{lcccccccc}
\hline P1 & silt & 6.3 & 2.7 & 0.14 & 0.01 & 3 & 0 & 0 \\
P2 & silt & 5.0 & 5.5 & nd & & 0 & 0 & 6 \\
P3 & silt & 5.0 & 5.5 & 0.53 & 0.02 & 0 & 0 & 6 \\
P4 & silt & 5.0 & 5.5 & 0.37 & 0.01 & 0 & 0 & 6 \\
P5 & silt & 5.0 & 5.5 & 0.34 & 0.01 & 0 & 0 & 6 \\
P6 & silt & 5.0 & 5.5 & nd & & 0 & 0 & 6 \\
P7 & silt & 5.0 & 5.5 & 0.33 & 0.05 & 0 & 0 & 6 \\
P8 & silt & 5.0 & 5.5 & nd & & 0 & 0 & 0 \\
P9 & silt & 5.0 & 5.5 & nd & & 0 & 0 & 0 \\
T1 & silt & 4.9 & 5.8 & 0.22 & 0.03 & 0 & 1 & 1 \\
T2 & silt & 4.9 & 5.8 & nd & & 0 & 1 & 0 \\
T3 & organic & 4.7 & 14.6 & nd & & 2 & 0 & 0 \\
T4 & organic & 5.1 & 12.8 & nd & & 2 & 1 & 1 \\
Y1 & silt & 5.1 & 3.4 & 0.15 & 0.02 & 1 & 1 & 0 \\
Y2 & silt & 5.1 & 3.4 & nd & & 1 & 1 & 0 \\
Y3 & silt & 5.1 & 3.4 & 0.20 & 0.01 & 1 & 1 & 0 \\
Y4 & silt & 4.7 & 1.7 & 0.23 & 0.04 & 2 & 1 & 1 \\
A1 & silt & 4.9 & 5.0 & 0.22 & 0.05 & n/a & n/a & 3 \\
A2 & silt & 4.9 & 5.0 & 1.15 & 0.06 & n/a & n/a & 3 \\
A3 & silt & 5.2 & 2.1 & 0.26 & 0.03 & n/a & n/a & 3 \\
H1 & sand & 5.0 & 1.7 & nd & & 3 & 3 & 3 \\
H2 & sand & 5.0 & 1.7 & nd & & 3 & 3 & 3 \\
H3 & sand & 5.0 & 1.7 & 0.26 & 0.02 & 3 & 3 & 3 \\
H4 & sand & 5.0 & 1.7 & 0.14 & 0.00 & 3 & 3 & 3 \\
H5 & sand & 5.0 & 1.7 & 0.20 & 0.03 & 3 & 3 & 3 \\
H6 & sand & 5.0 & 1.7 & 0.18 & 0.02 & 3 & 3 & 3 \\
H7 & sand & 5.0 & 1.7 & nd & & 3 & 3 & 3 \\
H8 & sand & 5.0 & 1.7 & 0.31 & 0.07 & 0 & 0 & 3 \\
E1 & silt & 5.0 & 1.3 & nd & & 3 & 0 & 0 \\
E2 & silt & 5.0 & 1.3 & nd & & 3 & 0 & 0 \\
\hline pH & C $(12.75)$ & & & & & & & \\
\hline
\end{tabular}

${ }^{1} \mathrm{pH}$ in $\mathrm{CaCl}_{2}(1: 2.5)$.

${ }^{2}$ nd, not detected.

${ }^{3}$ Spraying times, dosage per 1 spraying ca. $0.4 \mathrm{~L} \mathrm{ha}^{-1} ; \mathrm{n} / \mathrm{a}$, not available. 